\title{
Corporate Social Responsibility Performance \& ETF Historical Market Volatility
}

\author{
Vasiliki A. Basdekidou ${ }^{1} \&$ Artemis A. Styliadou ${ }^{2}$ \\ ${ }^{1}$ SRFA, Aristotle University of Thessaloniki, Greece \\ ${ }^{2}$ School of Law, Aristotle University of Thessaloniki, Greece \\ Correspondence: Vasiliki A. Basdekidou, Special Research Fund Account (E $\Lambda$ KE), Aristotle University of \\ Thessaloniki, Greece. Tel: 30-697-277-5475. E-mail: Vasiliki.Basdekidou@ gmail.com
}

Received: July 12, 2017

doi:10.5539/ijef.v9n10p30
Accepted: July 31, 2017

Online Published: August 25, 2017

\begin{abstract}
In investment and trading, different CSR moral ethical firms, categorized in a number of groups, may be suitable for different financial instruments (i.e. USA sector ETFs) and different market volatility situations. For the purpose of this article we first (i) analyze the trading return performance of four CSR categories (in particular: activism, community development, corporate governance, and environment); and then (ii) examine and comment the correlation between the market performance of a number of firms belonging in these four CSR categories and historical ETF market volatility. Finally, we (iii) suggest CSR firms as trading tools according to dominant market volatility. Other CSR categories (like: fair trade \& supply chain, green building, philanthropy \& corporate contributions, etc.) would be examined in future research by following the introduced by this paper approach. Paper concludes that, in relatively less volatile markets the Environment CSR ethical firms display better results. On the other hand, in strong market volatile situations it is better to trade Community Development CSR and Corporate Governance CSR ethical firms. Finally, the Activism CSR ethical firms are uncorrelated with the market volatility, as well as their performance is poor in all market cases.
\end{abstract}

Keywords: corporate social responsibility, ethical investing, historical market volatility, CSR categories

JEL Classification: G10, G14, G18, M20

\section{Introduction}

The main goal of this paper is to suggest and propose CSR ethical firms as trading tools according to dominant market volatility, after the examination and comment of the correlation between a number of US Corporate Social Responsible (CSR) ethical firms and the underlined market volatility (Ang et al., 2006; Angel \& Rivoli, 1997; Leung, Lorig, \& Pascucci, 2015; Little, 2010). For this purpose, firstly, a performance analysis has been conducted and four CSR categories (Activism, Community Development, Corporate Governance, and Environment) were considered on selecting the CSR ethical firms for this performance analysis (Note 1).

CSR Activism: Activism is the concept, dogma or practice of dynamic and effective action including direct-action campaigns (e.g. writing letters to newspapers and politicians), demonstrations, embargos, rallies, strikes, and in some cases, guerilla protest tactics, as a means of achieving political, cultural, and social change.

CSR Community Development: Community development is the process by which civil, urban and national leaders, activists, local citizens, and professionals improve various aspects of local and urban communities. It empowers and entrusts individuals with the skills needed to effect change, including building political and social power and working for a common agenda based on values of fairness, opportunity, and social justice.

CSR Corporate Governance: Corporate governance refers to the structure, schema and value, which determine corporate direction, power and performance. The framework depends on the legal, constitutional, juridical, legitimate, regulatory, institutional, and ethical, moral, and righteous environment of the company's stakeholder community.

CSR Environment: Environment is the complex network (web) of physical, chemical, technical, biological, psychological, social, and cultural conditions, settings and circumstances that influence an organism, a system, or an ecological community. 
In order to calculate the historical market volatility, we used the well known in technical analysis ATR technical indicator divided by the average of the last 60 monthly candlestick bars. The average true range (ATR) is a measure of market volatility introduced first by Welles Wilder in his classic book, "New Concepts in Technical Trading Systems" (Wilder, 1978). The True Range technical indicator is the greatest of the following: current High less the current Low, the absolute value of the current High less the previous Close and the absolute value of the current Low less the previous Close. The Average True Range (ATR) is a moving average (generally for a 14-day period) of the True Ranges.

\subsection{Problem Introduction}

Trading in all of its forms (i.e. investing, swing trading, and intraday trading) is regarded as a temporal historical and psychological living system (Elder, 2014; Styliadis, 2007; Styliadis \& Vassilakopoulos, 2005; Tsoutsoura, 2004) with a number of time-based anomalies calling for, claiming, challenging and contradicting the well-known efficient-market hypothesis (EMH) and initiating and launching a number of relative trading functions. According to bibliography, anomalies in the markets appear infrequently (occasionally) and challenge the EMH (Note 2).

The EMH theory claims that the current price of a security or asset reflects all public and private information, including the psychological dimension, about that security or asset. Thus, a "market" (e.g. a stock or a 3x instrument) follows the path of a random walk hypothesis (RWH) (derived from a weak-form EMH), the evidence, thesis and proof of which states that current prices are not dependent on past prices and are normally distributed over time (Malkiel, 2003; Moskowitz, Ooi, \& Pedersen, 2012; Orlitzky, 2013).

According to EMH and RWH, changes in price are due to current news or events and the psychological time, which obviously are impossible to predict in advance. The current article says that the EMH and RWH both ignore the realities of the markets (emotional factors), in that the participants are not completely rational and that current price moves are not independent of previous moves (Lou, Polk, \& Skouras, 2016; Edelen, Ince, \& Kadlec, 2015; Tsoutsoura, 2004; Ahn, Conrad, \& Dittmar, 2003; Asness, Moskowitz, \& Pedersen, 2013).

Investing and trading CSR firms is a complicated operation related on both, the firm itself (CSR category) and the underlined trading and temporal functionalities involved in the trading financial instrument, that is to say the USA sector ETF (Note 3). Hence, selecting the (leveraged) ETF in the appropriate CSR category is a great and profitable job (Nguyen \& Tran, 2016; Ogden \& Wu, 2013; Orlitzky, 2013; Basdekidou \& Styliadou, 2017).

\subsection{Paper's Motivation}

The main motivation of this article is the introduction, for the first time in literature, of a close-form "advise" on selecting CSR ethical firms as trading tools according to dominant market volatility. The proposed close-form "advise" has been structured after the examination and comment of the correlation between a number of US Corporate Social Responsible (CSR) ethical firms and the underlined market volatility. For this purpose, firstly, a performance analysis has been conducted regarding the involved CSR categories of the CSR ethical firms (Tsoutsoura, 2004; Orlitzky, 2013).

The link between market volatility and CSR firms' categories is complicated and it is for interest for the speculators, investors, swing traders, hedgers, and intraday traders. For instance, speculators in sideways range-bound markets (i.e. choppy markets) profit from time-series momentum trading strategies at the expense of hedgers; and swing traders, in trending markets (i.e. non-choppy markets), profit from time-series momentum trading strategies at the expense of intraday traders and (long-term) investors (Barclays \& Hendershott, 2003; Asness, Moskowitz, \& Pedersen, 2013; Tsoutsoura, 2004).

In this domain, the main target of the current article is contrasting and dissimilar. Actually, we investigate both cases as trading concepts: (a) whether the CSR categories involved in trading returns; and (b) whether the market volatility, historically, influence the ETFs profits. It is notable that, the results obtained do depend on the trading instrument (i.e. CSR category) and the grade of the underlined market volatility. Therefore always an adaptive personalized functionality is involved ("volatility" in case of the trading instrument and "user profile" for the case of the investors, swing traders, intraday traders and momentary speculators) (Basdekidou \& Styliadou, 2017).

Apart from the four CSR categories investigated in this article, other CSR categories for future investigation and research are:

Academia: Academia refers to a university, college, academy, and/or associated educational, training or research activities. Also used as the collective term for the community (staff and faculty) engaged in higher education and research. 
Economic Development: The continuous (sustained), combined actions of policy makers, civil engineers, architects, landscape architects, urban surveyors, rural engineers and communities that promote the standard of living and economic health of an urban or rural region.

Fair Trade \& Supply Chain: Fair Trade is a trade that satisfies criteria and benchmarks relative to the supply chain of the goods and conditions involved; usually including fair payment for producers, money management procedures and other social and environmental considerations. It is a part of an organized social movement and concept, which promotes standards and benchmarks for international labor, sociology, environmentalism, and social policy in commerce between developed and undeveloped countries.

Green Building: Green building is a design concept and a construction practice of increasing the efficiency of buildings and their use of energy, water, wood, and other materials, and reducing building impacts on human health and the environment.

Green Products \& Services: Natural and Organic Products are food and non-food products as well, which have been involved, produced and processed in compliance with laws, regulations, benchmarks, and agreements that typically exclude ingredients and/or manufacturing techniques of contaminants, toxic, pollutant, and harmful chemicals.

Human Resources \& Diversity: The terms "Human Resources \& Diversity" refers to a variety of issues, which employees and employers use to face while at work; including labor relations, diversity - age, gender, skills, and race - health and safety, and discrimination and harassment as well. This category also covers all usual human resources (issues): from allowances, benefits and talent management to recruitment, reservation and rankings.

Philanthropy \& Corporate Contributions: The term "Philanthropy/Corporate Contribution" is a donation of funds, time, psychological support, resources, and in-kind services by companies to charitable, non-profit, and/or community initiatives with the intention of 'giving it back' from profit for the greater common good (Lou, Polk, \& Skouras, 2016).

\subsection{Paper's Structure}

The rest of the current paper is organized and formed as follows: In Section 2 ("Back-testing ETFs from four CSR categories") a relative top-down price action technical analysis approach is discussed, analyzed and demonstrated. In Section 3 ("Performance Evaluation - Results") four Tables tabulate the statistical data for these four CSR categories and then a comparative return analysis is presented. Finally, Section 4 ("Conclusions \& Future Research") summarizes the conclusions and discusses paper's innovations and contributions with future promising functionalities.

\section{Back-Testing ETFs from Four CSR Categories}

In this Section the top-down price action technical analysis market approach (based on the so-called Japanese "candlestick" representation) for the CSR ETFs is presented through the paradigm of the Time Warner (TWX) stock-instrument (Direxion, 2017; Worden, 2017).

In Figure 1 (a StockCharts.com courtesy), as an example of the top-down price action technical market approach, we display (a) "The Dark-Cloud Cover with a Bearish Confirmation" technical analysis candlestick pattern; and (b) "The Head \& Shoulders / neck-line" technical analysis price action pattern. The critical point in these situations is the psychological time as a warning dynamics signal (w!D) (Basdekidou \& Styliadou, 2017; Campbell et. al, 2014; Chemmanur, He, \& Hu, 2009). For more information and discussion about the so-called "psychological time" please see Livermore (1940/2001) and Lefèvre (1923/2010).

Other leveraged ETF with great CSR interest are the JNUG/JDST 3x leveraged pair (Figure 2; a StockCharts.com courtesy). The JNUG instrument is the $3 \mathrm{x}$ leveraged counterpart, while the JDST instrument is the $3 \mathrm{x}$ inverse-leveraged counterpart of the pair. In Figure 2, the top-down price action technical market approach for the JNUG instrument is displayed. For clarity purposes we call the JNUG as "instrument" instead of as a "stock", because it's trading behavior and price action is complicated and much different than that of a normal US (NYSE, NASDAQ, Arca) stock.

Actually, these two counterparts (JNUG and JDST), despite the fact that both have the same reference, that is to say the junior gold miners GDXJ ETF (Van Eck, 2017); they operate in exactly the same percentage ratio but in an opposite manner (i.e. $+3 \mathrm{x}-3 \mathrm{x}$ ). Actually, both follow a constantly declining price action procedure and this strange behavior, explained statistically by local-stochastic volatility models; see Cheng and Madhavan (2009); and Avellaneda and Zhang (2010), is a typical technical market anomaly.

In fact, in computational finance theory, leveraged (ETF) implied volatility from (ETF) dynamics (Leung et. al, 
2015; Lou, Polk, \& Skouras, 2016; Domenico D'Errico, 2017; Livermore (1940/2001); Lefèvre (1923/2010); Basdekidou, 2017a; Basdekidou, 2017b; Tsoutsoura, 2004; Orlitzky, 2013).

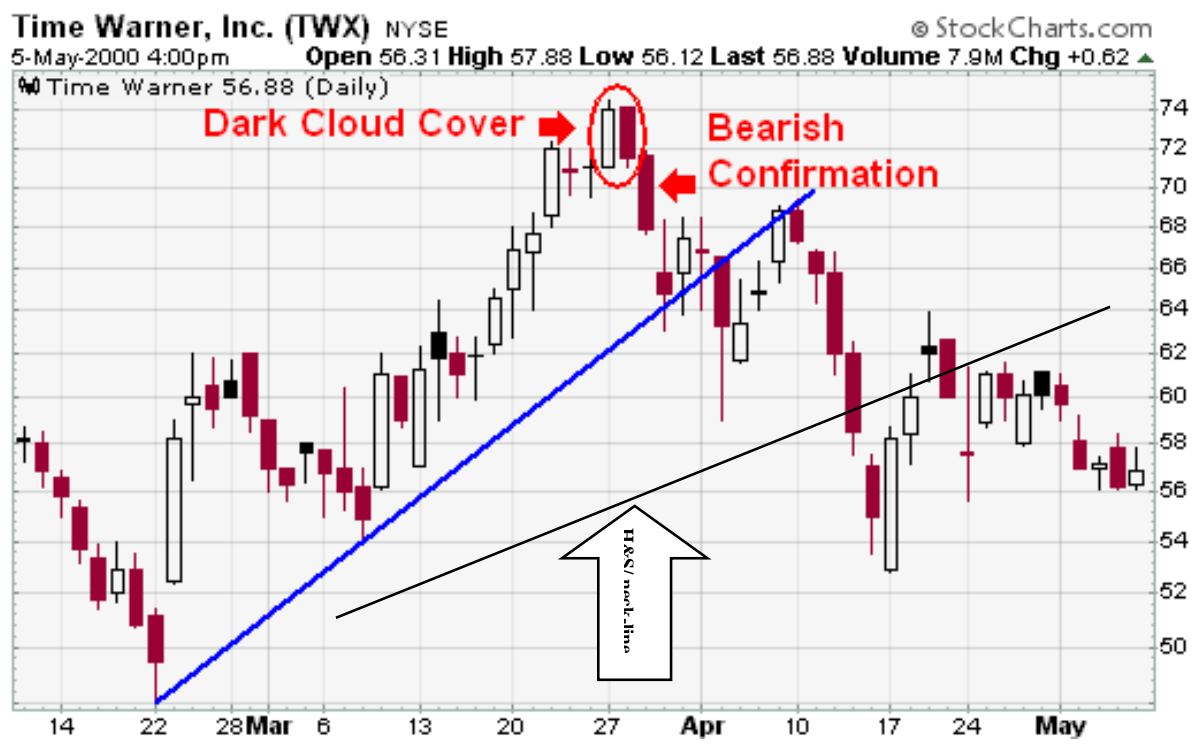

Figure 1. Time Warner (NYSE: TWX). A Psychological time TTF as w!D signal after the appearance of: (a) "The Dark-Cloud Cover with Bearish Confirmation" candlestick pattern; and (b) "The Head \& Shoulders / neck-line" price action pattern

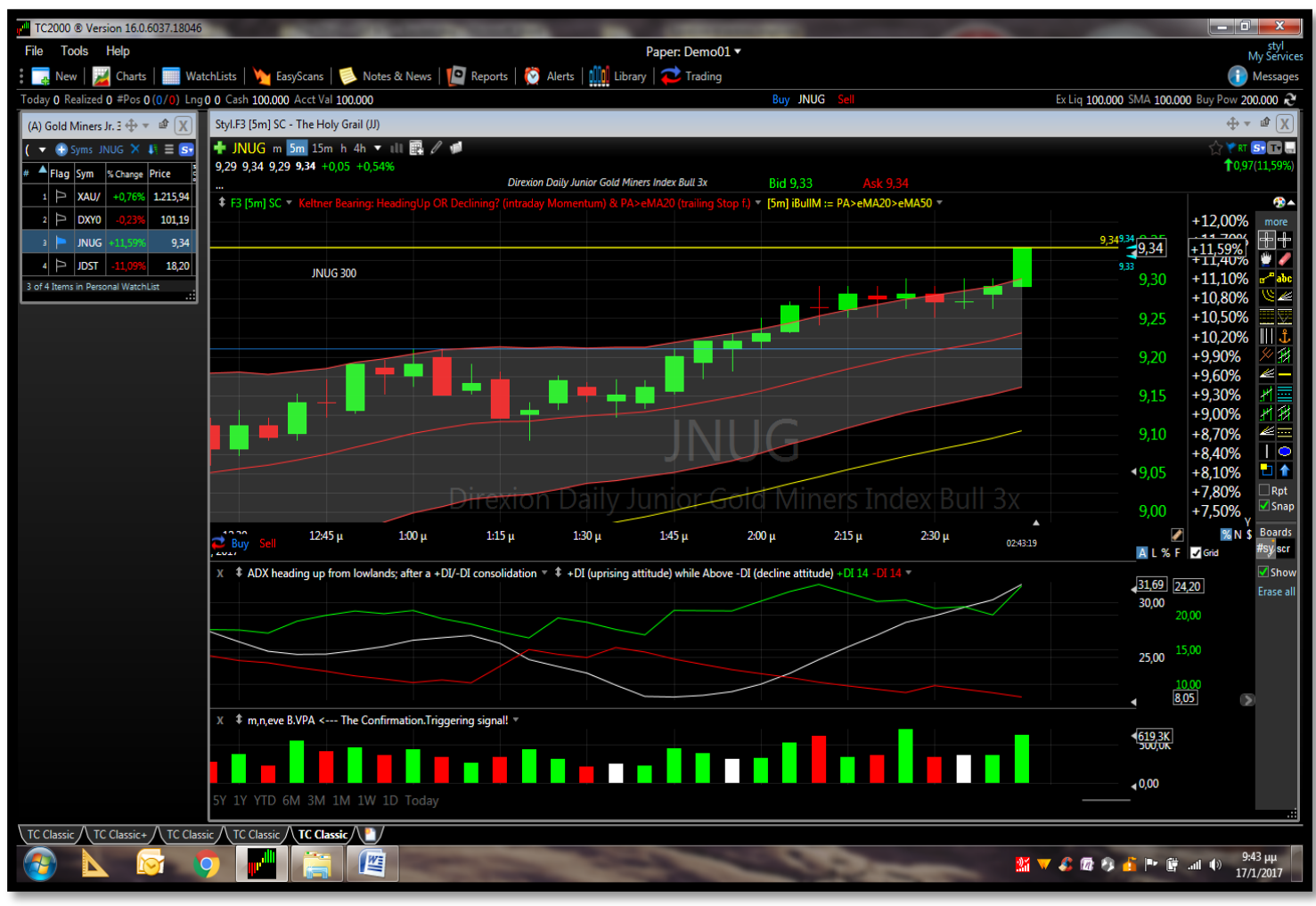

Figure 2. Gold Miners Juniors 3x ETF (Arca: JNUG). A Psychological time TTF as w!D signal after the appearance of: (a) "The Dark-Cloud Cover with Bearish Confirmation" candlestick pattern; and (b) "The Head \& Shoulders / neck-line" price action pattern

\section{Performance Evaluation - Results}

According to financial literature (Blackrock, 2010; Avellaneda \& Zhang, 2010; Ogden \& Wu, 2013; Basdekidou 
\& Styliadou, 2017) for trading plans and strategies, a back-test procedure is an applicable performance evaluation tool offering a number of functionalities. Hence, in order to check and assess the proposed in this article trading-strategy methodology (based on CSR categories and market volatility) we have back-tested it into a 5-year data-series for ten (10) ETFs (01.01.2012 - 31.12.2016 data). The back-test procedure has generated 203 trades and the results are presented in Tables 1,2,3, and 4; while a comparative, correlative and provisional return analysis for the back-testing procedure is discussed in the end of this Section (Domenico D'Errico, 2017; Ogden \& Wu, 2013; Basdekidou \& Styliadou, 2017; Orlitzky, 2013).

Following Table 1 is referred to the introduced CSR Activism morality ethics firms and presents, in summary, the Hit Rate (\%) and the Average Trade (\%) for the period: $1^{\text {st }}$ January $2012-31^{\text {st }}$ December 2016 (203 trades generated) for trending (non-choppy) market situations - correlation with volatility (\%) (Barron's, 2017).

Table 1. CSR activism - Backtesting results for CSR ethics firms from the activism CSR category. Backtesting procedure: $1^{\text {st }}$ January $2012-31^{\text {st }}$ December 2016

\begin{tabular}{ccccc}
\hline \multicolumn{5}{c}{ Back-testing Results on USA Sector ETFs } \\
\hline USA Sector ETF & Volatility $\%$ & No. of Trades & Hit Rate $\%$ & Average Trade $\%$ \\
\hline XLB & $9.2 \%$ & 203 & 44 & $0.12 \%$ \\
XLE & $10.4 \%$ & 203 & 39 & $-1.05 \%$ \\
XLF & $10.6 \%$ & 203 & 43 & $-0.44 \%$ \\
XLI & $7.7 \%$ & 203 & 53 & $0.64 \%$ \\
XLK & $7.5 \%$ & 203 & 43 & $0.40 \%$ \\
XLP & $5.2 \%$ & 203 & 38 & $-0.80 \%$ \\
XLU & $6.9 \%$ & 203 & 36 & $-0.82 \%$ \\
XLV & $6.7 \%$ & 203 & $-0.29 \%$ \\
XLX & $7.3 \%$ & 203 & 42 & $0.14 \%$ \\
XLY & $7.4 \%$ & 203 & 48 & $0.14 \%$ \\
Average & & & 48 & $-0.22 \%$ \\
Correlation with volatility $\%$ & & & 43 & $-0.07 \%$ \\
\hline
\end{tabular}

Following Table 2 is referred to the introduced CSR Community Development morality ethics firms and presents, in summary, the Hit Rate (\%) and the Average Trade (\%) for the period: $1^{\text {st }}$ January $2012-31^{\text {st }}$ December 2016 (203 trades generated) for trending (non-choppy) market situations - correlation with volatility (\%) (Barron's, 2017; Tsoutsoura, 2004).

Table 2. CSR community development - Backtesting results for CSR ethics firms from the community development CSR category. Backtesting procedure: $1^{\text {st }}$ January $2012-31^{\text {st }}$ December 2016

\begin{tabular}{ccccc}
\hline \multicolumn{5}{c}{ Back-testing Results on USA Sector ETFs } \\
\hline USA Sector ETF & Volatility $\%$ & No. of Trades & Hit Rate $\%$ & Average Trade $\%$ \\
\hline XLB & $9.2 \%$ & 203 & 53 & $1.38 \%$ \\
XLE & $10.4 \%$ & 203 & 63 & $1.31 \%$ \\
XLF & $10.6 \%$ & 203 & 43 & $-1.37 \%$ \\
XLI & $7.7 \%$ & 203 & 57 & $1.29 \%$ \\
XLK & $7.5 \%$ & 203 & 48 & $-0.23 \%$ \\
XLP & $5.2 \%$ & 203 & 48 & $0.28 \%$ \\
XLU & $6.9 \%$ & 203 & 50 & $0.16 \%$ \\
XLV & $6.7 \%$ & 203 & 46 & $-0.03 \%$ \\
XLX & $7.3 \%$ & 203 & 54 & $0.12 \%$ \\
XLY & $7.4 \%$ & 203 & 54 & $0.13 \%$ \\
Average & & & 50 & $0.33 \%$ \\
Correlation with volatility $\%$ & & & 0.37 & $0.05 \%$ \\
\hline
\end{tabular}

Following Table 3 is referred to the introduced CSR Corporate Governance morality ethics firms and presents, in summary, the Hit Rate (\%) and the Average Trade (\%) for the period: $1^{\text {st }}$ January $2012-31^{\text {st }}$ December 2016 (203 trades generated) for trending (non-choppy) market situations - correlation with volatility (\%) (Barron's, 2017; Tsoutsoura, 2004). 
Table 3. CSR corporate governance - Backtesting results for CSR ethics firms from the corporate governance CSR category. Backtesting procedure: $1^{\text {st }}$ January $2012-31^{\text {st }}$ December 2016

\begin{tabular}{ccccc}
\hline \multicolumn{5}{c}{ Back-testing Results on USA Sector ETFs } \\
\hline USA Sector ETF & Volatility $\%$ & No. of Trades & Hit Rate $\%$ & Average Trade $\%$ \\
\hline XLB & $9.2 \%$ & 203 & 49 & $-0.10 \%$ \\
XLE & $10.4 \%$ & 203 & 57 & $0.77 \%$ \\
XLF & $10.6 \%$ & 203 & 53 & $0.73 \%$ \\
XLI & $7.7 \%$ & 203 & 43 & $-0.11 \%$ \\
XLK & $7.5 \%$ & 203 & 38 & $-1.20 \%$ \\
XLP & $5.2 \%$ & 203 & 48 & $0.38 \%$ \\
XLU & $6.9 \%$ & 203 & 50 & $-0.16 \%$ \\
XLV & $6.7 \%$ & 203 & 47 & $0.16 \%$ \\
XLX & $7.3 \%$ & 203 & 52 & $1.11 \%$ \\
XLY & $7.4 \%$ & 203 & 53 & $1.11 \%$ \\
Average & & & 49 & $0.18 \%$ \\
Correlation with volatility $\%$ & & & 0.43 & $0.29 \%$ \\
\hline
\end{tabular}

Finally, Table 4 is referred to the introduced CSR Environment morality ethics firms and presents, in summary, the Hit Rate (\%) and the Average Trade (\%) for the period: $1^{\text {st }}$ January $2012-31^{\text {st }}$ December 2016 (203 trades generated) for trending (non-choppy) market situations - correlation with volatility (\%) (Barron's, 2017).

Table 4. CSR environment - Backtesting results for CSR ethics firms from the environment CSR category. Backtesting procedure: $1^{\text {st }}$ January $2012-31^{\text {st }}$ December 2016

\begin{tabular}{ccccc}
\hline \multicolumn{5}{c}{ Back-testing Results on USA Sector ETFs } \\
\hline USA Sector ETF & Volatility $\%$ & No. of Trades & Hit Rate $\%$ & Average Trade $\%$ \\
\hline XLB & $9.2 \%$ & 203 & 46 & $0.50 \%$ \\
XLE & $10.4 \%$ & 203 & 48 & $-0.37 \%$ \\
XLF & $10.6 \%$ & 203 & 48 & $-1.45 \%$ \\
XLI & $7.7 \%$ & 203 & 50 & $0.38 \%$ \\
XLK & $7.5 \%$ & 203 & 48 & $0.05 \%$ \\
XLP & $5.2 \%$ & 203 & 48 & $0.30 \%$ \\
XLU & $6.9 \%$ & 203 & 45 & $-0.03 \%$ \\
XLV & $6.7 \%$ & 203 & 48 & $0.19 \%$ \\
XLX & $7.3 \%$ & 203 & 51 & $0.14 \%$ \\
XLY & $7.4 \%$ & 203 & 52 & $0.15 \%$ \\
Average & & & 49 & $-0.03 \%$ \\
Correlation with volatility $\%$ & & & -0.01 & $-0.61 \%$ \\
\hline
\end{tabular}

\subsection{Comparative \& Correlative Return Analysis}

A comparative, correlative and provisional return analysis, according to Tables 1, 2, 3, and 4, indicates that the Activism CSR category performance is poor. Actually, it performs only on five (5) out of the ten (10) USA ETF sectors, with an average trade of $-0.22 \%$ and a $43 \%$ hit rate. The Community Development CSR category performance is profitable on seven (7) out of the ten (10) USA ETFs, with a positive $0.33 \%$ average trade and $50 \%$ hit rate. The Corporate Governance CSR category performance is profitable on six (6) out of the ten (10) USA ETFs, with a positive $0.18 \%$ average trade and $49 \%$ hit rate. Finally, the Environment CSR category performance is profitable on seven (7) out of the ten (10) USA ETFs, with a slightly negative $-0.03 \%$ average trade and 49\% hit rate (Domenico D'Errico, 2017; Tsoutsoura, 2004; Orlitzky, 2013).

Also, according to Tables 1, 2, 3, and 4, the Activism CSR performances are uncorrelated with ETF volatility, which means that no matter what the market historical volatility is, this category performance is poor (Vayanos \& Woolley, 2013). Even more, the Community Development CSR and Corporate Governance CSR performances are positively correlated with the ETFs' historical market volatility. That is to say, these two CSR ethical categories perform better on volatile markets. Finally, the correlation results on the fourth Environment CSR category, show that its trading performance is negatively correlated with market volatility (historically). 
Hence, trading ethical CSR firms belonging in this category (Environment CSR) is much more profitable in case of less volatile markets (Tsoutsoura, 2004; Blackrock, 2010; Basdekidou, 2017a; Avellaneda \& Zhang, 2010; Basdekidou, 2017b).

\section{Conclusions \& Future Research}

According to the comparative and correlation return analysis presented in the previous Section, investing and trading CSR ethics firms, through the ETF financial instruments, depends both on market volatility and the hosted CSR category (Vayanos \& Woolley, 2013; Basdekidou, 2015; Basdekidou, 2016a; Domenico D'Errico, 2017; Basdekidou, 2016b; Basdekidou, 2017c; Tsoutsoura, 2004; Orlitzky, 2013). For the purpose of this paper we examine and analyze both (i) the trading return performance of four CSR categories (Activism, Community Development, Corporate Governance, and Environment); and (ii) the correlation between the firm's trading performance of these four CSR categories and the underlined involved historical market volatility. We conclude that, in relatively less volatile markets the Environment CSR ethical firms display better results (i.e. long-term investing and trading returns). On the other hand, in strong market volatile situations it is better to trade (i.e. short-term trading) Community Development CSR and Corporate Governance CSR firms. Finally, the Activism CSR ethical firms are uncorrelated with the market volatility, as well as their performance is poor in all market cases. That is to say, Activism CSR firms are not for long-term investing or short-term trading in US markets.

Further future research could follow the same statistical approach and investigate (for the interest of trading) the correlation of market volatility into a number of other CSR categories like: Economic Development, Fair Trade \& Supply Chain, Green Building, Green Products \& Services, Human Resources \& Diversity, Philanthropy \& Corporate Contributions, etc.

\section{Acknowledgments}

We would like to thank the anonymous reviewers for their careful reading of the manuscript and their many insightful comments and suggestions. Also, the financial support (covering mainly the CoT/CFTC, Zacks, and the Barron's \& WSJ.com market data expenses) from the EU/LLP Programme "EPOCHE 2014" (with Project No. 2013-1-GR1-ERA10-15376) is gratefully acknowledged.

\section{Conflicts of Interest}

The authors have not declared any conflict of interest with the companies, ETFs, and market quotes appeared on this article. Also, on writing and publishing this paper they have no position in any stocks, ETF, ETN and trading instruments mentioned.

\section{Disclaimer}

The approaches and trading strategies provided on this article are general information services for the public. The author is not an investment advisor, and she does not endorse or recommend any securities, ETFs or other investments. Market quotes and certain other information on this article, as well as reference materials or links to sites, have been compiled unbiased from publicly available sources believed to be reliable and are for general informational and research purposes only. The accuracy or completeness of the information, approaches, plans and trading strategies contained herein is not guaranteed and is not intended to be relied upon for investment purposes.

\section{References}

Ahn, D. H., Conrad, J., \& Dittmar, R. F. (2003). Risk adjustment and trading strategies. The Review of Financial Studies, 16, 459-485. http://dx.doi.org/ 10.1093/rfs/hhg001

Ang, A., Hodrick, R. J., Xing, Y., \& Zhang, X. (2006). The Cross-Section of Volatility and Expected Returns. Journal of Finance, 61, 259-299. http://dx.doi.org/10.1111/j.1540-6261.2006.00836.x

Angel, J. J., \& Rivoli, P. (1997). Does Ethical Investing Impose a Cost upon the Firm? A Theoretical Perspective. Journal of Investing, 6(4), 57-61. http://dx.doi.org/10.3905/joi.1997.57

Asness, C., Moskowitz, T. J., \& Pedersen, L. H. (2013). Value and Momentum Everywhere. The Journal of Finance, LXVIII(3), 929-985. http://dx.doi.org/10.1111/jofi.12021

Avellaneda, M., \& Zhang, S. (2010). Path-Dependence of Leveraged ETF Returns. SIAM Journal of Financial Mathematics, 1, 586-603.. http://dx.doi.org/10.1137/090760805

Barclay, M. J., \& Hendershott, T. (2003). Price Discovery and Trading After Hours. The Review of Financial Studies, 16(4), 1041-1073. http://dx.doi.org/10.1093/rfs/hhg030

Barron's Financial Investment News and Market Data. (2017). Retrieved from http://www.barrons.com/data; and 
http://www.wsj.com; and http://www.wsj.com/europe

Basdekidou, V. A. (2015). Functionality, Returns and Efficiency before and after the Debt Crisis: An Empirical Analysis of the Greek Stock Market (Unpublished doctoral dissertation). Bulgarian Academy of Sciences Economic Research Institute, Bulgaria.

Basdekidou, V. A. (2016a). IPO Trading with Short-term and Intraday Temporal Functionalities. Business and Economics Journal, 7(4). http://dx.doi.org/10.4172/2151-6219.1000257

Basdekidou, V. A. (2016b). Personalized Temporal Trading Functionalities Engaged in Calendar Market Anomalies: Empirical Evidences from the 2007 and 2009 Financial Crises. Journal of Business \& Financial Affairs, 5(4). http://dx.doi.org/10.4172/2167-0234.1000225

Basdekidou, V. A. (2017a). Seasoned Equity Offerings as Technical Market Anomalies: Long-Term Temporal Trading Functionalities. International Journal of Economics and Finance, 9(1), 96-105. http://dx.doi.org/10.5539/ijef.v9n1p96

Basdekidou, V. A. (2017b). The Overnight Return Temporal Market Anomaly. International Journal of Economics and Finance, 9(3), 1-10. http://dx.doi.org/10.5539/ijef.v9n3p1

Basdekidou, V. A. (2017c). The Momentum \& Trend-Reversal as Temporal Market Anomalies. International Journal of Economics and Finance, 9(5), 1-20. http://dx.doi.org/10.5539/ijef.v9n5p1

Basdekidou, V. A., \& Styliadou, A. A. (2017). Technical Market Anomalies: Leveraged ETF Trading with Daily and Intraday Temporal Functionalities. Business and Economics Journal, 8(1). http://dx.doi.org/10.4172/2151-6219.1000275

Blackrock, Inc (2010). ETF Landscape Year End 2009 Preview Report. Retrieved from http://www.BlackRock.com

Campbell, J. Y., Giglio, S., Polk, C., \& Turley, R. (2014). An Intertemporal CAPM with Stochastic Volatility. London School of Economics and Political Sciences working paper, LSE London, UK. https://pdfs.semanticscholar.org/0044/748cabfc0ee3f7fdeea1992ce8efd7aaaa5f.pdf

Chemmanur, T. J., He, S., \& Hu, G. (2009). The role of institutional Investors in Seasoned Equity Offerings. Journal of Financial Economics, 94, 384-411. http://dx.doi.org/10.1016/j.jfineco.2008.12.011

Cheng, M., \& Madhavan, A. (2009). The Dynamics of Leveraged and Inverse-Exchange Traded Funds. Journal of Investment Management, 7(4), 43-62. Retrieved from https://ssrn.com/abstract=1393995 or http://www.q-group.org/wp-content/uploads/2014/01/Madhavan-LeverageETF.pdf

D’Errico, D. (2017). Detecting Swings. Technical Analysis of Stocks \& Commodities, 35(6), 24-26, 39.

Direxion Investments. (2017). ETFs and Funds: Bold trades on Gold Miners - in either direction. Retrieved from http://www.direxioninvestments.com/ or http://www.direxioninvestments.com/gold-miners

Edelen, R. M., Ince, O., \& Kadlec, G. B. (2015). Institutional Investors and Stock Return Anomalies. E- Journal SSRN. http://dx.doi.org/10.2139/ssrn.2359744

Elder, A. (2014). The new Trading for Living: Psychology, Discipline, Trading Tools and Systems, Risk Control, Trade Management (p. 312). Wiley Trading Series. Retrieved from http://eu.wiley.com/WileyCDA/WileyTitle/productCd-1118443926.html

Lefèvre, E. (2010). Reminiscences of a Stock Operator (In J. D. Markman, Annotated edition, p. 448). Hoboken, NJ: John Wiley \& Sons, Inc. Retrieved from http://eu.wiley.com/WileyCDA/WileyTitle/productCd-0470481595.html

Leung, T., Lorig, M., \& Pascucci, A. (2015). Leveraged ETF implied volatilities from ETF dynamics. Retrieved from http://www.spdr-etfs.com

Little, P. K. (2010). Inverse \& Leveraged ETFs: Not Your Father's ETF. The Journal of Index Investing, 1(1), 83-89. http://dx.doi.org/10.3905/jii.2010.1.1.083

Livermore, J. (2001). How to Trade in Stocks (R. Smitten, Translation, p. 179). New York, NY: McGraw-Hill. (Original work published 1940). https://www.amazon.com/How-Trade-Stocks-Business-Books/dp/0071469796

Lou, D., Polk, C., \& Skouras, S. (2016). A Tug of War: Overnight versus Intraday Expected Returns. London School of Economics and Political Sciences working paper, LSE London, UK. Retrieved from http://personal.lse.ac.uk/loud/overnightmom.pdf 
Malkiel, B. G. (2003). A Random Walk Down Wall Street (p. 463). New York, NY: W. W. Norton \& Company. Retrieved from http:// http://site.iugaza.edu.ps/wdaya/files/2013/

Moskowitz, T. J., Ooi, Y. H., \& Pedersen, L. H. (2012). Time series momentum. Journal of Financial Economics, 104, 228-250. http://dx.doi.org/ 10.1016/j.jfineco.2011.11.003

Nguyen, X. M., \& Tran, Q. T. (2016). Dividend Smoothing and Signaling Under the Impact of the Global Financial Crisis: A Comparison of US and Southeast Asian Markets. International Journal of Economics and Finance, 8(11), 118-123. http://dx.doi.org/10.5539/ijef.v8n11p118

Ogden, J. P., \& Wu, S. (2013). Reassessing the Effect of Growth Options on Leverage. Journal of Corporate Finance, 23, 182-195. http://dx.doi.org/10.1016/j.jcorpfin.2013.08.008

Orlitzky, M. (2013). Corporate Social Responsibility, Noise, and Stock Market Volatility. The Academy of Management Perspectives, 27(3), 238-254. Business School / University of South Australia, Adelaide, Australia. https://doi.org/10.5465/amp.2012.0097

Styliadis, A. D. (2007). E-learning Documentation of Historical Living Systems with 3-d Modeling Functionality. Informatica, 18(3), 419-446. Retrieved from http://www.mii.vu.lt/informatica/pdf/INFO686.pdf

Styliadis, A. D., \& Vassilakopoulos, M. G. (2005). A Spatio-Temporal Geometry-based Model for Digital Documentation of Historical Living Systems. Information \& Management, 42(2), 349-359. http://dx.doi.org/10.1016/j.im.2004.01.006

Tsoutsoura, M. (2004). Corporate Social Responsibility and Financial Performance. Applied Financial Project (Center of Responsible Business, Haas School of Business, University of California at Berkeley). Retrieved from http://escholarship.org/uc/item/111799p2

Van, E. (2017). https://www.VanEck.com (formerly Market Vectors ETFs)

Vayanos, D., \& Woolley, P. (2013). An Institutional Theory of Momentum and Reversal. Review of Financial Studies, forthcoming. London School of Economics and Political Sciences working paper. LSE London, UK. Retrieved from http://personal.lse.ac.uk/vayanos/Papers/ITMR_RFS13.pdf

Wilder, W. J. Jr. (1978). New Concepts in Technical Trading Systems (p. 130). Hunter Publishing Company. Winston-Salem \& Greensboro, NC: Trend Research. Retrieved from http://rls.bsd.com.br/ rls/Classicos/Welles\%20Wilder\%20-\%20New\%20Concepts\%20in\%20Technical\%20 Trading\%20Systems.pdf

Worden. (2017). http://www.tc2000.com/

\section{Notes}

Note 1. CSR - Corporate Social Responsibility. Also called Corporate Conscience, Corporate Citizenship or Responsible Business, is a form of corporate self-regulation integrated into a business model. CSR policy functions as a self-regulatory mechanism whereby a business monitors and ensures its active compliance with the spirit of the law, ethical standards and national or international norms. Critics questioned the "lofty" and sometimes "unrealistic expectations" in CSR or that CSR is merely window-dressing, or an attempt to pre-empt the role of governments as a watchdog over powerful multinational corporations. Political sociologists became interested in CSR in the context of theories of globalization, neoliberalism and late capitalism. Some sociologists viewed CSR as a form of capitalist legitimacy and in particular point out that what began as a social movement against uninhibited corporate power was transformed by corporations into a 'business model' and a 'risk management' device, oft en with questionable results. CSR is titled to aid an organization's mission as well as serve as a guide to what the company represents for its consumers. Business ethics is the part of applied ethics that examines ethical principles and moral or ethical problems that can arise in a business environment. ISO 26000 is the recognized international standard for CSR. Public sector organizations (the United Nations for example) adhere to the triple bottom line (TBL). It is widely accepted that CSR adheres to similar principles, but with no formal act of legislation.

Note 2. EMH - Efficient Market Hypothesis. The efficient market hypothesis is an investment theory that states it is impossible to "beat the market" because stock market efficiency causes existing share prices to always incorporate and reflect all relevant information. According to the EMH, stocks always trade at their fair value on stock exchanges, making it impossible for investors to either purchase undervalued stocks or sell stocks for inflated prices. As such, it should be impossible to outperform the overall market through expert stock selection 
or market timing, and the only way an investor can possibly obtain higher returns is by purchasing riskier investments.

Note 3. ETF - Exchange Traded Fund. An ETF is a marketable security that tracks an index, a commodity, bonds, or a basket of assets like an index fund. Unlike mutual funds, an ETF trades like a common stock on a stock exchange. ETFs experience price changes throughout the day as they are bought and sold. ETFs typically have higher daily liquidity and lower fees than mutual fund shares, making them an attractive alternative for individual investors. Because it trades like a stock, an ETF does not have its Net Asset Value (NAV) calculated once at the end of every day like a mutual fund does.

\section{Copyrights}

Copyright for this article is retained by the author(s), with first publication rights granted to the journal.

This is an open-access article distributed under the terms and conditions of the Creative Commons Attribution license (http://creativecommons.org/licenses/by/4.0/). 